\title{
A SANTÍSSIMA TRINDADE NOS SERTÕES: SEVERINO TAVARES E A GESTAÇÃO DO MOVIMENTO MESSIÂNICO-MILENARISTA DE PAU DE COLHER (CASA NOVA, BAHIA, 1934-1938)
}

\author{
THE HOLY TRINITY IN THE HINTERLANDS: \\ SEVERINO TAVARES AND THE BIRTH OF THE MESSIANIC-MILLENARIAN MOVEMENT \\ OF PAU-DE-COLHER (CASA NOVA, BAHIA, 1934-1938)
}

Filipe Pinto Monteiro*

\begin{abstract}
RESUMO: A proposta do artigo é analisar a gestação de um movimento social de cunho religioso em Pau de Colher, no município de Casa Nova, interior da Bahia, na década de 1930, a partir das similitudes e diferenças que o vinculam a outras duas manifestações de religiosidade popular, identificadas em Juazeiro do Norte (1889-1934), de Padre Cícero Romão Batista (1844-1934) e Caldeirão dos Jesuítas (1926-1936), do beato José Lourenço Gomes da Silva (1872-1946). A investigação será encaminhada tendo por base a trajetória particular de um personagem, o beato Severino Tavares, que possibilitou demonstrar o elo entre os três movimentos.
\end{abstract}

Palavras-chave: Pau de Colher, Severino Tavares, Messianismo

ABSTRACT: The purpose of this paper is to analyze the birth of a religious social movement in Pau de Colher, in the municipality of Casa Nova, Bahia's inland, in the 30s, from the similarities and differences that bind it to other two manifestations of popular religiosity, identified in Juazeiro do Norte (1889-1934), of Padre Cicero Romão Batista (1844-1934) and Caldeirão dos Jesuítas (1926-1936), of blessed José Lourenço Gomes da Silva (1872-1946). The investigation will be forwarded based on the trajectory of a particular personage, blessed Severino Tavares, which enabled to demonstrate the link between the three movements.

Key-words: Pau de Colher, Severino Tavares, Messianism

Todo Baiano

já havia esquecido

Do que passou-se em Canudos

Por causa de um bandido

Quando surgiu este caso

Que acho bem parecido

Com Severino Tavares

Pessoa de Zé Lourenço

Enviado do Padre Cícero

Dizia: Eu sou quem venço!

Aqui eu dou "dia santo"

E vai sair como eu penso!...

Francisco Severino. Façanhas do beato Zé Lourenço em Pau de Colher. ${ }^{1}$

Estudos acadêmicos de relevância sobre movimentos religiosos de cunho messiânico e milenarista surgiram no Brasil a partir do final dos anos 50 e início dos anos 60 do século XX. Os chamados movimentos messiânicos receberam especial atenção, sobretudo de antropólogos,

\footnotetext{
* Aluno do Programa de Pós-graduação em História Social na UFRJ, onde desenvolve a dissertação: $A$ gestação e 0 impacto político do movimento messiânico-milenarista de Pau de Colher (Sertão da Bahia, 1934-1938), sob orientação da Prof. ${ }^{a}$ Dr. ${ }^{a}$ Jacqueline Hermann.

1 SEVERINO, Francisco. Façanhas do Beato Zé Lourenço em Pau de Colher. Folheto, s.d.
} 
sociólogos e jornalistas que produziram trabalhos importantes naquele momento. Refiro-me a uma tradição sócio-antropológica que, se por um lado perdeu sua pujança nos últimos anos, por outro nos legou um conjunto valioso de pesquisas monográficas ${ }^{2}$ ou, o que era mais habitual, afinadas com tendências da época - como o estruturalismo, o funcionalismo ou o marxismo. ${ }^{3}$

As produções de cunho historiográfico foram raras, ou por dificuldade de acesso às fontes ou porque o tema não havia se constituído ainda como campo de interesse para os historiadores. Pau de Colher, movimento que ocorreu no município de Casa Nova, interior da Bahia, entre os anos de 1934 e 1938, não fugiu à regra. As primeiras investigações consistentes sobre o caso apareceram em 1965 no clássico 0 messianismo no Brasil e no mundo, da socióloga Maria Isaura Pereira de Queiroz. ${ }^{4}$ Mas 0 grande responsável por colocar Pau de Colher entre as principais manifestações messiânicas brasileiras foi o antropólogo Raymundo Duarte, professor da UFBA, que expôs seu primeiro trabalho em 1969 sob o titulo Notas preliminares de estudo do movimento messiânico de Pau de Colher. 5 O impacto do movimento na região foi profundo, mobilizou forças policiais e militares de três estados (Pernambuco, Bahia e Piauí), envolveu questões políticas e religiosas, chegando inclusive ao conhecimento do presidente da República, Getúlio Vargas (1882-1954).

$\mathrm{O}$ pequeno povoado de Pau de Colher situava-se em pleno semi-árido nordestino, distante aproximadamente $90 \mathrm{~km}$ da sede do município de Casa Nova, que fazia fronteira ao norte com os estados de Pernambuco e Piauí. Fundado como distrito de Riacho de Casa Nova na primeira metade do século XIX pelo então capitão e depois coronel da Guarda Nacional, José Manuel Viana, foi desmembrado da cidade de Remanso de Pilão Arcado (atual Remanso) e registrado como município de São José do Riacho de Casa Nova, recebendo seu atual nome reduzido por decreto apenas em 19316.

\footnotetext{
2 CASTALDI, Carlo. A aparição de demônio em Catulé. In: QUEIROZ, Maria Isaura Pereira de et al. Estudos de sociologia e história. São Paulo, Inep - Anhembi, p. 17-130, 1957; FACÓ, Rui. Cangaceiros e fanáticos. Gênese e lutas. Rio de Janeiro: Civilização Brasileira, 1963, entre outros.

3 PEREIRA DE QUEIROZ, Maria Isaura. O messianismo no Brasil e no mundo. São Paulo: Dominus/Edusp, 1965; QUEIROZ, Mauricio Vinhaz de. Messianismo e conflito social. A guerra sertaneja do Contestado: 1912-1916. Rio de Janeiro: Civilização Brasileira, 1966, entre outros.

4 PEREIRA DE QUEIROZ, Maria Isaura. Op. cit. 282.

5 Esse trabalho foi resultado de uma pesquisa realizada sob orientação de Thales de Azevedo que o cita em livro: "Ocorrência de 1938, o surto fanático de Pau-de-Colher, entre Pernambuco e Bahia, vem sendo reconstruído e analisado, por Raimundo Duarte, sob nossa orientação [...]." Ver: AZEVEDO, Thales de. Cultura e situação racial no Brasil. Rio de Janeiro: Civilização Brasileira, 1966, p. 126; DUARTE, Raymundo. Notas preliminares de estudo do movimento messiânico de Pau de Colher. In: IV Colóquio Internacional de Estudos Luso-Brasileiros. Salvador, 1969.

6 CASA NOVA, Bahia (BA), Histórico. Disponível em: $<$ <ttp://www.ibge.gov.br/cidadesat/historicos_cidades/historico_conteudo.php?codmun=290720>. Acesso em: quatro de abril de 2010; REMANSO, Bahia (BA), Histórico. Disponivel em: $<$ <ttp://biblioteca.ibge.gov.br/visualizacao/dtbs/bahia/remanso.pdf>. Acesso em: quatro de abril de 2010
} 
A cidade estava na região do Vale do São Francisco, ou, mais especificamente, em área que se convencionou chamar de Baixo Médio São Francisco e tinha a peculiaridade de concentrar dentro de seus limites tanto a área banhada pelo rio - dominada pela cultura dos beradeiros, praticantes da agricultura de vazante e dependentes do comércio fluvial -, quanto aquela que se encontra longe da influência de suas águas, em meio às veredas alto-sertanejas, habitada pelos catingueiros, onde ocorreu o movimento de Pau de Colher.

Em 1977, o município teve de ser transferido de lugar devido à construção da barragem para a hidroelétrica da Cachoeira de Sobradinho, empreendimento sob responsabilidade da Companhia Hidrelétrica do São Francisco (CHESF). ${ }^{7} 0$ movimento religioso que iremos analisar ocorreu originalmente na Casa Nova Velha, que se encontra hoje submersa sob as águas do Lago de Sobradinho. 8

Neste vasto território, apareceu perambulando no início dos anos 30 um beato penitente chamado Severino Tavares, que se dizia da mesma "disciplina" de Padre Cícero Romão Batista (18441934) - conhecido por seu papel de destaque em Juazeiro do Norte (1889-1934) -, e de José Lourenço Gomes da Silva (1872-1946), que liderou o movimento do Caldeirão dos Jesuítas (1926-1936). Nossa investigação - que resultou na elaboração do primeiro capítulo de nossa dissertação, aprovada pela Banca de Qualificação da UFRJ em abril de 2010 - identificou em Severino a responsabilidade pela circulação de idéias e crenças que originaram outro movimento religioso em Pau de Colher e, tendo por base fontes inéditas, aprofundou o estudo da ligação entre os três movimentos citados.

\section{SEVERINO, MEU "PADRIM CONSELHEIRO"}

Desde o nosso primeiro contato com a comunidade religiosa de Pau de Colher suspeitamos que a sua gestação guardasse íntimos vínculos com o desenvolvimento dos movimentos de Juazeiro e Caldeirão. Não fomos, porquanto, os únicos. Raymundo Duarte ${ }^{9}$, Maria Alba G. M. Mello ${ }^{10}$ e Roberto

\footnotetext{
7 O lago de Sobradinho cobriu as cidades originais de Casa Nova, Pilão Arcado, Remanso e Santo Sé.

8 A decisão da construção da barragem de Sobradinho se deu em 1972 e em 1974 começaram os trabalhos de esclarecimento dos sertanejos sobre a necessidade de saírem de suas casas. 0 município de Casa Nova foi escolhido como sede da equipe de trabalho responsável por preparar as ações de "Transferência da população" que se completou em 1977. Ver: MARTINS-COSTA, Ana Luiza Borralho. Uma retirada insólita: a representação camponesa sobre a formação do Lago de Sobradinho. 1989, p. 218-223. Dissertação (Mestrado) - Programa de Pós-Graduação em Antropologia Social, Universidade Federal do rio de Janeiro, Rio de Janeiro.

9 DUARTE, Raymundo. Um movimento messiânico no interior da Bahia. In: SCHADEN, Egon (org.). Homem, Cultura e Sociedade no Brasil, Petrópolis: Vozes, 1972, p. 326-250 (Seleções da Revista de Antropologia).

10 MELLO, Maria Alba Guedes Machado. O movimento messiânico de Pau de Colher (uma reconstituição histórica). Revista da Bahia, Salvador, v.33, n.19, p. 52-59, 1991.
} 
Malvezzi ${ }^{11}$ apontaram para a mesma direção, mas não avançaram nas pesquisas. Maria Isaura Pereira de Queiroz também identificou em Padre Cícero os condicionantes remotos de outras experiências de caráter messiânico/milenarista no nordeste brasileiro:

A partir do movimento em que dois grandes santos autóctones figuraram nos oratórios rústicos
- Padre Cícero, no Nordeste e João Maria, no sul - polarizaram em torno de si a espera
messiânica, e as lendas correntes gravitaram-lhes em redor. Daí em diante passaram a ser os
heróis messiânicos, e se reencarnaram em várias figuras, dando lugar ora a embriões de
movimentos, prestes abafados, ora a movimentos que plenamente desabrocharam. Enquanto
no sul não temos notícia de nenhum importante pela sua extensão e duração, no nordeste
vários tiveram lugar, dignos de estudos que apenas começam a ser efetuados. ${ }^{12}$

Ao aprofundar as leituras e a investigação da documentação coletada, alguns vestígios nos levaram a crer na consistência dessa hipótese. Paralelo às constantes referências a José Lourenço nas fontes documentais e iconográficas que se referem a Pau de Colher, Padre Cícero também era presença simbólica entre os habitantes da comunidade. Isso foi comprovado, por exemplo, pelos militares pernambucanos responsáveis pela ação repressora ao movimento que se deu em fevereiro de 1938, ao recolherem medalhas com imagens do sacerdote espalhadas entre os pertences dos moradores, findo o conflito.

Ainda assim, não era possível fundamentar a afirmação, visto que ambos os personagens eram figuras emblemáticas e muito presentes no cotidiano e no discurso da população sertaneja da região do Baixo Médio São Francisco no período em análise. Logo, precisávamos de um elemento concreto, de um dado seguro e relevante que possibilitasse demonstrar a ligação entre os personagens supracitados e os fenômenos religiosos que lideraram.

Encontramo-lo ao perseguir o rastro de um enigmático beato chamado Severino Tavares, com o qual nos ocuparemos neste artigo. Tal possibilidade se deve à característica singular da trajetória de Severino que permitiu sua circulação por diferentes espaços dos sertões, entre os quais podemos incluir seguramente Caldeirão e Pau de Colher e possivelmente, Juazeiro do Norte. Ele seria, portanto, a ponte entre as três manifestações religiosas, como tentaremos expor nas linhas seguintes.

Antes, porém, de rastrearmos os passos do beato, apresentaremos sucintamente as peculiaridades dos movimentos liderados por Padre Cícero e Zé Lourenço - apenas nos pontos que tangenciam o nosso objeto de estudo -, que consideramos indispensáveis para se compreender 0 processo de gestação do messianismo em Pau de Colher e a própria formação religiosa de Severino.

\footnotetext{
11 MALVEZZI, Roberto. A história de Pau de Colher - o último grande movimento messiânico do Brasil. s.d. (mimeo).

12 PEREIRA DE QUEIROZ, Maria Isaura. Op. Cit., p. 282.
} 
Juazeiro do Norte, cidade do interior do Ceará, se configura hoje como um grande centro de devoção católica e popular. Isso se deve à atuação política e religiosa de Padre Cícero Romão Batista (1844-1934) que chegou ao povoado em 1872, como sacerdote recém-ordenado pelo Seminário Diocesano de Fortaleza. Cícero foi o personagem central de um grave conflito político e religioso que envolveu toda a região do Vale do Cariri, no extremo sul do atual Estado do Ceará, em um momento conturbado da história do país, no qual se assistia à passagem da Monarquia para a República. ${ }^{13}$

Em uma de suas primeiras iniciativas, Padre Cícero criou em Juazeiro as irmandades de caridade, ordens religiosas que se tornaram muito populares e reuniam grupos de mulheres (a entrada de homens só foi permitida após 1903) que, sob sua supervisão e autoridade, se tornaram beatas e lhe auxiliaram nas práticas de devoção no povoado. Seguia ele o exemplo do missionário José Antônio Pereira Ibiapina (1806-1883), com o qual conviveu por pouco tempo, e que foi o responsável por implementar na mesma região as irmandades de freiras e Casas de Caridade ${ }^{14}$, com objetivo de promover ações de auxílio entre a população carente, na segunda metade do século XIX. ${ }^{15}$

No ano de 1889, num momento em que Padre Cícero já era fonte de grande veneração popular, uma de suas beatas, Maria de Araújo (1862-1914), uma jovem de 28 anos, ao receber a comunhão em um dos rituais em honra do Sagrado Coração de Jesus, na Capela de Nossa Senhora das Dores, teria visto a imaculada hóstia se transformar em sangue na sua boca. Diziam, era sangue de Jesus Cristo. O milagre do sangue ou milagre da hóstia como ficou conhecido, se repetiu diversas vezes, se espalhou por toda a região do Cariri e transformou Juazeiro em um efervescente centro de romaria e devoção popular. ${ }^{16}$

O bispo de Fortaleza, o paulista Dom Joaquim José Vieira (1836-1917) decidiu criar uma Comissão Episcopal de Inquérito, instalada em 1891. Os comissários, liderados pelo padre Clycério da Costa Lobo (Chefe-comissário) e padre Francisco Ferreira Antero (Secretário), após testemunharem a repetição do suposto milagre, chegaram à conclusão de que os eventos em Juazeiro tinham sim origem divina e alertaram para a possibilidade do despertar uma "igreja dentro da igreja". ${ }^{17}$

\footnotetext{
13 DELLA CAVA, Ralph. Milagre em Juazeiro. Rio de Janeiro: Paz e Terra, 1976, p. 38.

14 Ibiapina fundou Casas de Caridade em Missão Velha, Crato, Barbalha e Milagres.

15 Muito embora alguns escritores católicos condenem essa comparação, documentos revelam que a presença dessas mulheres no ensino ocasional do catecismo, nos serviços anuais da Semana Santa e nos autos de Natal, entre outras ações, mostra uma similitude na orientação devocional de ambos os missionários. Ver: DELLA CAVA, Ralph. Op. Cit., p. 38.

${ }^{16}$ DELLA CAVA, Ralph. Op. Cit., p. 40.

17 Della Cava levanta a hipótese de que determinados fatores como a separação entre Igreja e Estado, promovida pela República recém-proclamada, o inicio do proselitismo protestante no interior cearense em 1891, o "indiferentismo religioso" de Roma com o Brasil em matéria de reconhecimento de feitos milagrosos e o conflito com os padres lazaristas franceses, incentivaram os membros da comissão a endossar o milagre.
} 
Duas grandes teses foram alentadas com relação às graves implicações teológicas que 0 milagre poderia suscitar. ${ }^{18} \mathrm{~A}$ que mais nos interessa está relacionada diretamente ao fenômeno do advento do milênio ou milenarismo. Muitos acreditavam que o milagre era um sinal do fim dos tempos, da chegada do apocalipse. O discurso milenarista alimentou os fiéis dessa expectativa, sendo responsável pela adesão de muitos sertanejos ao que alguns já entendiam como um "cisma em potencial".

Juazeiro se transmutava em um autêntico "movimento", dotado de organizações formais, como as irmandades ${ }^{19} \mathrm{e}$ as Ordens de Penitentes ${ }^{20}$ que giravam em torno de uma crença comum: os milagres de Maria de Araújo. Se as beatas foram um importante instrumento para o fortalecimento do movimento e para a propagação do discurso milenarista, o surgimento dos beatos penitentes também contribuiu para a sua expansão. Muitos deles eram responsáveis pela organização das rezas e cantorias, além do auxilio nos trabalhos manuais de obras de caridade e do plantio e colheita, assim como na ajuda de serviços religiosos, tanto ao ar livre como na própria capela da cidade.

Entre os milhares de romeiros que chegaram na primeira onda de peregrinos a Juazeiro do Norte em 1890 estava o paraibano de Pilões de Dentro, José Lourenço Gomes da Silva (? - 1946), que viria a se tornar um dos homens de grande influência junto ao "Patriarca do Cariri". Zé Lourenço, logo que chegou à cidade, ingressou em uma das Ordens dos Penitentes e se destacou devido à sua excepcional devoção. Passou a liderar seções de autoflagelação (geralmente, com uso do cilício), cantorias e rezas junto a cruzeiros, em frente a capelas ou cemitérios.

Com o desenvolvimento econômico e o prestigio político de Juazeiro - cidade que viria a alcançar autonomia municipal em $1911^{21}$ com ajuda de Padre Cícero - as ondas de romeiros à cidade se tornaram cada vez mais intensas e esta não conseguiu mais absorver tamanha quantidade de fiéis. Tendo isso em mente e ciente da capacidade e preparação doutrinária do beato Lourenço, Cícero Ihe arrendou em 1926 um pequeno sítio de sua propriedade conhecido como Caldeirão dos Jesuítas²2 ou

\footnotetext{
18 DELLA CAVA, Ralph. Op. Cit., p. 54.

${ }^{19}$ Entre as mais importantes irmandades de Juazeiro destacamos a Legião da Cruz, o Apostolado do Sagrado Coração de Jesus, a Confraria de Nossa Senhora das Dores, de São Vicente de Paulo, do Santíssimo Sacramento e do Precioso Sangue.

20 Para mais detalhes sobre essas ordens ver: PEREIRA DE QUEIROZ, Maria Isaura. Os penitentes. In: Idem. 0 campesinato Brasileiro. Ensaios sobre civilização e grupos rústicos no Brasil. Petrópolis: Vozes, 1976. (Estudos brasileiros/3).

$21 \mathrm{O}$ distrito de Juazeiro foi desmembrado do município do Crato e elevado à categoria de vila pela lei estadual $\mathrm{n}^{\circ} 1028 \mathrm{em}$ 02 de julho de 1911. Em 23 de julho de 1914, pela lei estadual $n^{\circ} 1178$, a vila é elevada à condição de cidade, tendo como seu primeiro prefeito padre Cícero.

$22 \mathrm{O}$ nome do sítio vem de uma grande formação rochosa de mais ou menos dois metros de profundidade que conservava água em seu interior, também chamado de "Caldeirão de Pedra". Ao que tudo indica, a palavra "jesuítas" estaria fazendo
} 
Caldeirão de Santa Cruz do Deserto, localizado no município do Crato, no sopé da Serra do Araripe, Ceará, com vistas ao escoamento dos retirantes da "Cidade Santa". Importante salientar que o beato não tinha a posse jurídica dessas terras, apenas o direito de ocupá-las, sem nenhuma obrigação pecuniária para seu estabelecimento.

Zé Lourenço passou a exercer uma inconteste liderança carismática, estipulando uma hierarquia entre seus homens de confiança e delegando funções aos seus novos "secretários". Entre eles, dois se destacavam: Isaías, encarregado do comércio (interno e externo) da comunidade e o beato Severino Tavares, incumbido de angariar adeptos por todos os rincões nordestinos, uma espécie de "relações públicas" do movimento. Severino pode ser incluído numa grande leva de cidadãos norterio-grandenses que migraram para Caldeirão. Lemuel Silva e Orivaldo Junior ${ }^{23}$, citando estudos de Rui Facó 24 e outros, comprovam que em um universo de aproximadamente duas mil e quinhentas pessoas habitantes do sítio, aproximadamente $75 \%$ eram de origem potiguar. Entre os fatores identificados pelos autores para explicar o fluxo migratório, foram citados: demissões em massa no governo Rafael Fernandes (1935), lutas entre facções políticas, repressão contra os levantes comunistas de 1935 e a miséria provocada pelas constantes secas. Mas eles chamam a atenção também para 0 fato de que outros motivos, de ordem religiosa, despertavam nessas populações a esperança de novas possibilidades de vida, sonhos e fantasias.

Em 1934, após a morte de Padre Cícero, muitos romeiros se voltaram para o Caldeirão Grande, como também ficou conhecido, pois àquela altura a comunidade havia se transformando em um grande centro de catolicismo popular. A partir daquele momento passou a ser alimentada a crença de que Caldeirão era um espaço sagrado, uma terra prometida onde todos poderiam encontrar conforto espiritual e o lugar para o qual, provavelmente, Padre Cícero retornaria.

Em 1936, Caldeirão foi destroçado por forças militares do Estado do Ceará. O ano fora especialmente tenso, as autoridades ainda estavam temerosas em vista do malogrado levante comunista de 1935 que atingiu Rio de Janeiro, Pernambuco e Rio Grande do Norte. Esse foi um dos fatores que levaram a comunidade a ser tratada não apenas como um reduto de "fanáticos", mas também como uma possível célula comunista, montada para "levantar as massas camponesas", sob a

referência, de acordo com a tradição oral, aos padres jesuítas que se estabeleceram no local fugindo das perseguições pombalinas no século XVIII. Ver: RAMOS, Francisco Régis Lopes. Caldeirão. Fortaleza: EDUECE, 1991.

23 SILVA, Lemuel Rodrigues da. e JUNIOR, Orivaldo Lopes. Catolicismo popular e migração no nordeste: os sertanejos do Rio Grande do Norte em busca do "Paraíso Cristão". In: BINGEMER, Maria Clara Luchetti; NEUTZLING, Inácio e MAC DOWELL, João A. (orgs). A Globalização e os Jesuitas. Origens, História e impactos. Belo Horizonte: Faculdade Jesuíta de Filosofia e Teologia, 2006.

24 FACÓ, Rui. Cangaceiros e fanáticos. Gênese e lutas. Rio de Janeiro: Civilização Brasileira, 1963. 
liderança subversiva de Zé Lourenço. Assim noticiava o Diário da Noite em 1936:

\begin{abstract}
Foi agora descoberto um outro núcleo de fanáticos: em Caldeirão, no município cearence do Crato. Esse núcleo foi tomado pela imprensa como um bando de communistas, vivendo em pleno regime soviético [...]

$\mathrm{O}$ beato Lourenço, tomando conta do logar, começou por rebellar-se contra 0 fisco. Ninguém mais pagava imposto. Lei, justiça, religião - tudo estava concentrado na pessoa do beato. Elle era um déspota. Um sultão matuto. ${ }^{25}$
\end{abstract}

Apesar de uma investigação preliminar ter concluído que os sertanejos não possuíam armas ou promoviam qualquer atividade criminosa, a Diocese do Crato, proprietários de terra, a polícia estadual e o Governo do Ceará decidiram por sua eliminação.

\title{
O ANDARILHO SEVERINO EM PAU DE COLHER
}

Entre 1932 e 1935, portanto antes da destruição de Caldeirão, o "secretário" Severino Tavares realizou uma extensa peregrinação por toda região do Baixo Médio São Francisco, passando pelos municípios de São Raimundo Nonato, Remanso, Santo Sé e Casa Nova. Neste último, pregou em diversas localidades: Castanheiro, São José, Santa Cruz, Queimadas, Ouricouri, Surdo, Lagoa do Alegre e, por fim, Pau de Colher. ${ }^{26}$ Se dizendo emissário de Padre Cícero e representante de Zé Lourenço, se tornou conhecido como Padrim Conselheiro, conseguindo angariar muitos fiéis para Caldeirão. ${ }^{27}$ Como veremos adiante, a influência que exerceu sobre José Senhorinho, principal liderança em Pau de Colher, foi decisiva para o desenvolvimento do movimento religioso que aflorou sob regras e valores que sentam raízes em Juazeiro e Caldeirão.

O articulista Antônio de Alcântara Machado, do jornal O Povo, foi um dos primeiros a atentar para a prosperidade da comunidade de Zé Lourenço e o intenso proselitismo de Severino Tavares, em artigo escrito em 1935, valendo por isso a longa citação:

Dois malandros do Ceará, José Lourenço e Severino Tavares, andam explorando no Vale do Cariri a memória do Padre Cícero. Mas, explorando inteligentemente, de um modo que representa sem duvida um notável progresso sobre os processos até hoje adotados no sertão nordestino para fanatizar os coitados alucinados pela sêca.

\footnotetext{
25 OS ESPANTOSOS episódios do sertão do ceará. Diário da Noite, Recife, 22 de setembro de 1936, p. 1.

26 POMPA, Maria Cristina. Memória do fim do mundo: para uma leitura do movimento Sócio-religioso de Pau de Colher. 1995, p. 48. Dissertação (Mestrado em Antropologia) - Instituto de Filosofia e Ciências Humanas, Universidade Estadual de Campinas, Campinas.

${ }^{27}$ ESTRELA, Raimundo. Pau-de-colher: um pequeno Canudos. Salvador: Assembléia Legislativa do Estado da Bahia, 1998, p. 33.
} 
Os fiéis que êles atraem invocando o padrinho são obrigados ao trabalho. Não se limitam a rezar, construir igrejas, venerar os beatos, preparar o espírito para a bemavemturança eterna. São fanáticos não resta duvida. Mas fanáticos que lavaram a terra plantando cana e arroz. Severino alicia no sul do Ceará e Estados vizinhos o pessoal que José Lourenço dirige na lavoura do sitio do Caldeirão. Os romeiros se transformam em colonos e como colonos labutando de sol a sol é que salvam a alma.

$[\ldots]$

O sítio naturalmente prospera. Na propriedade serrana, que a sêca não atinge, as safras são cada vez mais vastas e mais compensadoras. Os dois sócios fantasiados de taumaturgos enriquecem. $E$ na imprensa já surgem protestos indignados contra essa nunca dantes imaginada exploração do trabalho pela astúcia, que também é um capital, como ninguém ignora. E que capital.

Exploração que a mim entretanto não é de todo antipática. Porque (como já disse) representa um progresso. E não deixa de ter sua utilidade. Os fanáticos que a lábia de José Lourenço e Severino atrai para o sitio do Caldeirão, são empregados no cultivo da terra. Para lucro exclusivo dos dois pândegos. Não. Pensam do bem, não. Para lucro da terra e dêles próprios também. [...] Deles fanáticos que afinal de contas recebem uma lição de trabalho. Não se embrutecem na ociosidade da crendice. De qualquer forma são úteis em seu fanatismo. Ganham com o próprio suor o pão alheio mas terminada a romaria não deixam no Caldeirão apenas uma capela como testemunho de sua religiosidade grosseira. Deixam também um campo cultivado como demonstração de seu trabalho.

[...] talvez regressem para as suas casas curados do mal da crendice. Como José Lourenço não é nenhum Antônio Conselheiro, não se limita a receber a veneração e fomentar o misticismo analfabeto dos fiéis, mas exige deles uma devoção em trabalho, Ihes impõe uma penitencia de tantas horas de enxada, é bem possível que cabem por dêscrer de iluminados e beatos.

[...] José Lourenço e Severino talvez estejam desmoralizando no Cariri a profissão de beato. É um serviço que o nordeste fica lhes devendo. 28

É fundamental notar que, apesar da constante utilização de termos pejorativos como "misticismo analfabeto", "religiosidade grosseira" e etc., o texto revela, ao contrário do que trabalhos anteriores tentaram provar, a total condenação dos beatos que tiveram alguma influência em Pau de Colher não era unanimidade na mídia impressa. Os discursos eram os mais diversificados, ainda que em sua grande maioria não fugissem à criminalização de movimentos desta natureza. É sintomática a comparação que Machado faz entre Zé Lourenço e Antonio Conselheiro. Ao diferenciar a atuação de ambos, ele está se posicionando na corrente oposta à que predominava na grande imprensa e que viu com naturalidade semelhanças entre Caldeirão, Pau de Colher e Canudos.

Mas o jornalista vai além e consegue enxergar algo de positivo no trabalho dos religiosos. "De qualquer forma são úteis em seu fanatismo", diz ele, tentando encontrar uma fórmula que pudesse explicar o inexplicável: o rápido e sustentável desenvolvimento de Caldeirão. Os "malandros" e "pândegos", Severino e Zé Lourenço, coordenaram junto com outros beatos a construção de dois açudes e a criação de oficinas de ferreiros, carpintaria e curtume na comunidade. Com o tempo, as

\footnotetext{
${ }^{28}$ MACHADO, Antônio de Alcântara. Os fanáticos do Caldeirão. O Povo, 2 de março de 1935, p. 3.
} 
atividades produtivas se diversificaram, era possível encontrar cerâmica, sabão, cestas e sacolas. ${ }^{29} \mathrm{De}$ fato, o sítio prosperou "naturalmente", porém, segundo relatos colhidos de sobreviventes por outros pesquisadores, ninguém era forçado a trabalhar e nem Zé Lourenço e, muito menos Severino, enriqueceram com essas atividades.

Como veremos com mais detalhes adiante, Pau de Colher foi destruído em 1938 por uma tropa militar procedente de Pernambuco. Manuel de Souza Ferraz, conhecido como "Manuel Flor", subcomandante da volante que atacou a comunidade, deixou um relato para a posteridade em que considera Severino a liderança mais perigosa entre os beatos do Caldeirão:

Na localidade denominada Pau-de-Colher, situada nos ermos longínquos do sertão baiano, numa área às fronteiras com os Estados de Pernambuco, Ceará e Piauí, armou-se 0 cenário de mais uma manifestação de fanatismo religioso.

Aí formara-se um núcleo de fanáticos com os mesmos adeptos que haviam reforçado as fileira de beatos e místicos que proliferaram no Caldeirão, no Ceará, sob a liderança de José Lourenço, o "Beato". Inconformados com a dissolução de seu "paraíso" em terras cearenses, não acompanharam a debandada com 0 antigo chefe e vieram estabelecer-se em Pau-deColher sob a liderança do mais radical de seus seguidores, Severino Tavares, também o executor da tarefa de aliciamento de fiéis para a seita do beato Lourenço, pela facilidade que possuía para entabular e manter prosas cativantes.

Esse trabalho era efetuado em todos os Estados limítrofes com o ceará e não demorou muito para que o movimento radical dos componentes da seita gerassem insegurança e protestos de pessoas que não aceitavam esse tipo de doutrinação que sempre descambava para as imposições e agressões ao encontrar resistência das pessoas.

[...] Em Pau-de-Colher, Severino Tavares continuou com suas atividades. Usava sempre barba comprida e vestia uma túnica semelhante a um hábito religioso, não excluindo o cordão franciscano à cintura; penitenciava-se carregando uma cruz às costas. 30

A primeira pesquisadora a levantar a hipótese de que a passagem de Severino por Pau de Colher foi um fator determinante para o surgimento de um movimento religioso na região foi, mais uma vez, Pereira de Queiroz. Segundo ela, "Em suas andanças, tinha Severino estado no lugarejo Pau de Colher [...]. Impressionou sobremaneira José Senhorinho; deu-lhe explicações religiosas, tornou-se seu mestre". ${ }^{31}$ Senhorinho, como será explicado mais a frente, foi a primeira liderança religiosa em Pau de Colher. Os ensinamentos do beato resultaram na construção de uma "clareira semicircular", conhecida como Circo dos Santos, onde rezas e cantorias coletivas eram praticadas e nome pelo qual, diz a autora, o movimento também era conhecido.

Raymundo Duarte afirma que Severino esteve na Bahia onde manteve contato com Senhorinho

\footnotetext{
${ }^{29}$ RAMOS, Francisco Régis Lopes. Op. Cit., p. 63-64.

30 FERRAZ, Marilourdes. O canto do Acauã: das memórias de Manuel de Souza Ferraz (Manuel Flor) um comandante das forças volantes. Belém. Pará: 1978, p. 469-470.

31 PEREIRA DE QUEIROZ, Maria Isaura. Op. Cit., p. 290.
} 
possivelmente entre 1933 e 1935², o que nos leva a crer que a gestação do movimento em Pau de Colher teve início, como indicam outros autores, por volta de 1934. Mas ele aponta para o fato de que esse primeiro contato é cercado de controvérsias. Inicialmente, imaginou-se que seria o próprio Zé Lourenço o responsável pela organização de um novo movimento no interior da Bahia, versão contestada pelas investigações de alguns jornais, como o Diário de Pernambuco, que estampou em uma edição de 1938:

A propósito dos motivos que vem circulando em torno dos fanáticos chefiados pelo beato Zé Lourenço, no Nordeste da Bahia, o Diário do Norte ouviu pessoa conhecedora do Nordeste, cujo nome não foi revelado. [...] Acredita-se que o beato Lourenço não tenha deixado o sitio de sua devoção que é precisamente na cidade de Padre Cícero. Tratar-se-ão de outros aventureiros. $^{33}$

Maria Cristina Pompa em sua dissertação de mestrado, intitulada Memória do fim do mundo: para uma leitura do movimento sócio-religioso de Pau de Colher, de 1995, provavelmente o trabalho mais completo sobre o tema até o momento, também dedicou um item do seu trabalho ao beato Severino. ${ }^{34}$ Segundo a autora, ele não parava em lugar algum por mais de dois ou três dias e, em geral, um grupo de pessoas do vilarejo visitado o acompanhava em procissão até o povoado seguinte, e de lá retornavam para suas casas. 0 conteúdo das pregações do "padrim conselheiro" fazia referência a um futuro de grandes privações, um porvir "apocalíptico".

Autor do livro mais conhecido sobre o caso do Caldeirão, Régis Lopes Ramos soube por intermédio do filho de Severino, Eleutério Tavares, que ele era camboeiro de profissão (espécie de tropeiro e caixeiro viajante) e que após conhecer Zé Lourenço passou a percorrer os sertões, sem se fixar em nenhum lugar. Em suas homilias, apontava sempre a chegada iminente do eschaton e que quando este viesse, os ricos teriam muitas dificuldades para se salvar. ${ }^{35}$ Pregava normas rígidas de comportamento, uma melhor educação dos pais para com os filhos, o desapego de bens materiais, a feitura do sinal da cruz e as orações diárias. ${ }^{36}$ Em seu livro de memórias, o médico Raimundo Estrela, responsável pela assistência médica às tropas que participaram da campanha contra Pau de Colher, diz que Severino vestia roupa preta, dizia-se viúvo e falava muito em Padre Cícero. Era baixo, calvo,

\footnotetext{
32 Ibid., p. 330.

${ }_{33}$ A AGITAÇÂO dos fanáticos na zona sertaneja do nordeste. Diário de Pernambuco, Fortaleza, 27 de janeiro de 1938.

34 POMPA, Maria Cristina. O início: o Conselheiro Severino. In: Idem. Op. Cit., p. 52.

35 RAMOS, Francisco Régis Lopes. Op. Cit., p. 141.

36 LEANDRO, Ana Lúcia Aguiar Lopes. Movimento de Pau de Colher na perspectiva dos atores sociais: relações entre significações da religião e da miséria. 2003, p. 120. Dissertação (Mestrado em Sociologia) - Centro de Filosofia e Ciências Humanas, Universidade Federal de Pernambuco, Pernambuco.
} 
analfabeto, usava alpercata e chapéu grande de feltro e era penitente há 10 anos. ${ }^{37}$

Assim que chegou a Pau de Colher, Severino encontrou algumas pequenas propriedades ocupadas por poucas famílias, entre elas a de Romualdo Ferreira da Costa e Eva Ferreira da Costa, onde entrou em contato com o filho do casal José Senhorinho Costa, que se tornaria peça chave para o nascimento do messianismo naquele lugarejo. A família Costa adquirira certo status, ao contrário de outras, pois acumulara boas roças onde plantavam algodão e mamona, produtos valiosos para venda. Também comercializava feijão, milho e mandioca na principal feira da região que era realizada todos os domingos debaixo de um juazeiro. ${ }^{38}$ Todavia, para além de seu incontestável domínio econômico, Senhorinho desfrutava de um enorme prestígio pessoal por ser uma das poucas pessoas alfabetizadas do lugarejo e ajudar o povo na compreensão das leituras que fazia dos textos bíblicos.

Segundo Duarte, "todos se impressionavam profundamente pelo fato de Senhorinho ter sido criado dentro do mato e ter aprendido a ler sem ter tido escola. Era considerado por todos como "macho na leitura" e capaz de calcular qualquer "distância". ${ }^{39}$ Em um lugar como Pau de Colher, desassistido de qualquer serviço público e com uma ligação por demais débil com a sede do município, a população desenvolveu estratégias de sobrevivência, principalmente ligadas ao atendimento à saúde e ao acompanhamento religioso. Neste ambiente, surgiam parteiras, como a mãe de senhorinho ou ainda curandeiros e rezadeiros, que como ele próprio, resguardavam para si uma série de conhecimentos respeitados e valorizados pela população. 40

Severino ficou hospedado na casa de Senhorinho por alguns dias e com ele estabeleceu uma forte amizade, contando-Ihe tudo sobre a experiência que vivera em Caldeirão. Após sua partida, deixou orientações claras para Senhorinho organizar seu povo sob determinadas leis "sagradas" e também o aconselhou a visitar Caldeirão, o que ele fez nos dois anos seguintes, levando gente de sua confiança. Esta experiência foi fundamental para sua formação, moldando os valores, os hábitos, normas, práticas

\footnotetext{
37 ESTRELA, Raimundo. Op. Cit., p. 120.

38 Apesar de ser à época uma área muito pobre - como o é até hoje -, Pau de Colher era passagem de tropas e boiadas que seguiam do Piauí e Ceará para a região norte/nordeste do país. Produtores locais, como os pais de Senhorinho, investiam apenas na produção agrícola de subsistência, cujo excedente ora era utilizado como moeda de troca com os viajantes, ora comercializado na feira local ou em outra maior, em Lagoa Alegre, a $10 \mathrm{~km}$ do povoado. A literatura que encontramos sobre as especificidades da economia de Casa Nova no final do século XIX e inicio do XX, invariavelmente refere-se a uma abundância de terras férteis, principalmente aquelas banhadas pelo velho Chico. Mas esses registros não levam em conta as diferenças entre as terras da caatinga e aquelas que margeiam o rio e possuem maior diversificação de suas culturas. Ver: MELLO, Maria Alba Guedes Machado. Op. Cit., p. 52-59; DUQUÉ, Ghislaine. Casa Nova: interventions du pouvoir et strategies paysannes. Un "municipe" du "sertão bahiano" à l'heure de La modernisation. 1980, 405 f. Thèse (Doctorat) - $3^{\circ}$ Cycle en Sociologie, Ecole Des Hautes Etudes en Sciences Sociales, Paris.

39 DUARTE, Raymundo. Notas preliminares de estudo do movimento messiânico de Pau de Colher. In: IV Colóquio Internacional de Estudos Luso-Brasileiros. Salvador, 1969, p. 15.

40 MELLO, Maria Alba Guedes Machado. Op. Cit., p. 52-59
} 


\section{A POLÍCIA NO ENCALÇO DO BEATO}

Após sua passagem por Pau de Colher, Severino se deteve em Remanso onde organizou um pequeno grupo de fiéis: 42

O beato Severino atingiu o município de Petrolina, (Fazenda Mudubim), vindo dos Estados do Piauhy e Ceará, depois de uma série de sangrentos combates com as forças policiaes destes dois estados fronteiriços a Pernambuco.

Em Mudubim já encontrou Severino, um grande grupo de fanáticos, que foram dispersados do grupo de Zé Lourenço, pelas forças cearenses. Ahi em Mudubim, Severino alliciou o maior numero de adeptos possíveis e foi se estendendo nessa catechese, até a Fazenda Poções, no município de Petrolina, indo localizar-se ao atravessar muitas fazendas do município de Casa Nova, Estado da Bahia, no logar denominado Pau de Colher.

Ali, Severino já acompanhado de numero avultado de crentes, rumou para a cidade de remanso, onde promoveu sermões em diversas noites, da sua estadia, em pleno campo, fazendo augmentar a avalanche de obcecados. ${ }^{43}$

A polícia municipal conseguiu prendê-lo, torturá-lo e expulsá-lo da cidade. ${ }^{44} \mathrm{Em}$ recente dissertação de mestrado, Francivaldo Silva afirma que a sua expulsão coincidiu com violentos embates políticos que se deram nesse município entre a família Castelo Branco e Francisco Leóbas, "o que aumentou o seu prestígio já que a luta travada entre chefes políticos é vista por parte da população como sendo a realização de suas visões proféticas". 45

A preocupação das autoridades com Severino aumentava na mesma proporção que o seu prestigio entre a população são-franciscana. Cid Carvalho, jornalista de 0 Pharol, nos dá algumas pistas do poder de persuasão de Severino:

Ninguém, de senso normal e instinctos humanisados, póde observar sem um brado de revolta, sem um grito de alerta para as autoridades constituídas, as conseqüências da acção nefasta, e dissolvente do bandido Severino Tavares, vulgo "Conselheiro" e de outros tantos

\footnotetext{
${ }^{41}$ As prédicas de Severino tiveram papel fundamental no crescimento populacional de Caldeirão. Em sua grande maioria, os romeiros que lá chegavam passavam vários dias em visita e depois retornavam às suas casas, mas a seca de 1932 e a morte de Padre Cícero em 1934, contribuíram para a permanência de muitos na comunidade. Ver: RAMOS, Francisco Régis Lopes. Op. Cit., p. 87.

42 Malvezzi afirma que Severino também formou um discípulo, conhecido como "seu Quim", que havia conhecido no porto de Malhadinha, distrito de Remanso. $O$ autor indica que muito provavelmente esse novo personagem seria o bato Quinzeiro, que aparecerá em Pau de Colher em 1937, se dizendo da "disciplina" de Severino. Entretanto, não temos no momento nenhuma fonte que confirme essa afirmação. Ao contrário, o que encontramos foi uma reportagem da Gazeta de Alagoas que afirma ser Quinzeiro filho de Severino. Ver: MALVEZZI, Roberto. OP. Cit.; AS INCURSÔES do beato José Lourenço através dos sertões nordestinos. Gazeta de Alagoas, Maceió, 27 de julho de 1938, p. 1.

${ }^{43}$ AS INCURSÔES do beato José Lourenço através dos sertões nordestinos. Op. Cit., p. 1.

44 SILVA, Francivaldo Mendes da. Pau de Colher: narrativas de luta e fé no sertão da Bahia. 2008, p. 85 e 88. Dissertação (Mestrado em História) - Centro de Filosofia e Ciências Humanas, Universidade Federal de Pernambuco, Recife.

45 lbid., p. 89.
} 
sectários do mal, que percorreram em romaria vasto trecho da região sanfranciscana [...].

Nas excursões feitas pelos aventureiros através dos nossos sertões, tamanha foi a ousadia dos mesmos e tão ampla foi a tolerância das autoridades policiaes, que o "Conselheiro" chegou a fazer as suas "pregações" até nas cidades, como se verificou em Remanso.

D'ahi a popularidade alcançada pelo audaz beato "Severino" que se dizia a "Terceira pessoa da Santíssima Trindade" no meio dos nossos incautos patrícios das aldeias e povoados, a ponto de n'um delles, quando em desobriga pelo interior da sua parochia, ser um sacerdote coagido e quase aggredido pela massa fanatisada, isto porque se mostrou contrário á falsa doutrina do perverso beato. ${ }^{46}$

0 trecho do artigo revela que em suas andanças, Severino não se conteve em pregar pelos povoados do interior, mas tentou arregimentar fiéis nas cidades. A suposta agressão ao padre pode também indicar um esforço dos clérigos em evitar a adesão de cristãos às tentadoras pregações do beato. Parece oportuno destacar do texto o fato de Severino se considerar a "Terceira pessoa da Santíssima Trindade", o que nos leva a considerar que as outras duas seriam Zé Lourenço e o próprio Padre Cícero, o que confirma a influência desses personagens em suas pregações. Isso fica mais claro em outra reportagem do jornal, que vincula Severino diretamente a seus predecessores:

Perseguidos pela policia cearense, no anno passado, os fanáticos de Zé Lourenço, que existem aos milhares no interior de Pernambuco, Bahia e Piauhy, não se deixaram vencer; os poucos foram se localizando em Pau de Colher, chefiados por Severino Tavares o "espírito santo" e segunda pessoa de Zé Lourenço, o enviado do Padre Cícero para salvar o seu povo, onde se entregavam ás estranhas "praticas" e "penitencias" attrahindo muita gente das vizinhanças. ${ }^{47}$

Estranhas "práticas" eram reproduzidas constantemente na imprensa regional, sempre em tom pejorativo. Em matéria da Gazeta de Alagoas, já aludida anteriormente, encontramos referência a alguns ritos religiosos estimulados por Severino que até então não tínhamos lido em nenhuma outra fonte ou relato de sobreviventes em pesquisas anteriores:

O beato Severino durante a noite, nas viagens, era vigiado e acariciado por sete moças fanáticas, das mais bonitas do seu grupo e pela manhã, era banhado por duas dellas em um quarto hermeticamente fechado emquanto os demais fanáticos ficavam do lado de fóra orando pelo falso enviado de Deus. Ao acabar o banho era essa falsa água engarrafada e distribuída aos fanáticos, que a bebiam e guardavam como uma relíquia, pois como dizia Severino, sendo um enviado de Deus, era um santo! $[\ldots]$

O beato Severino nas suas prédicas aos fanáticos, condemnava a religião catholica e apezar de ser ignorante a analphabeto pois assim dizia, lia correctamente e conhecia a fundo as religiões. E para fazer crer a sua força divina, elle lia e relia a bíblia de cabeça para baixo, dizendo áquelles pobres de espírito ser enviado de Deus.

$[.$.

${ }^{46}$ FANATISMO dissolvente e destruidor. O Pharol, Petrolina, 12 de março de 1938.

${ }^{47}$ FANATISMO! Banditismo! O Pharol, Petrolina, 3 de fevereiro de 1938. 


\begin{abstract}
Aconselhando aos seus adeptos que comprassem grande quantidade de sal o que deveria ser enterrado em saccos, Severino ia dominando pouco a pouco os seus vassalos. Deste modo as ordens foram cumpridas e muito sal foi enterrado, producto das vendas de muitos bens, daquella pobre gente que aconselhada por Severino foi arrastada á miséria e á morte!

Severino dizia aos seus asseclas que esta providencia do enterramento do sal era porque elle sentia que os fanáticos forçosamente mais tarde, seriam perseguidos pelos padres, e pelas forças do governo, e qualquer um fanático que morresse, ressuscitaria três dias após a morte.
\end{abstract}

É preciso, em ocasiões como essa, depurar as informações divulgadas para o grande público, com base no que já foi identificado e confrontado com outras fontes escritas ou orais. Tomar como falsas as informações publicadas na mídia impressa, como fizeram outros pesquisadores, pode se revelar um grande erro, tendo em vista que diversos dados parecem verdadeiros e foram corroborados por diferentes estudos, fontes e testemunhos.

É difícil acreditar na afirmação de que Severino condenava a religião católica, afinal a religiosidade elaborada tanto em Juazeiro como em Caldeirão e, posteriormente, em Pau de Colher, esteve ancorada essencialmente em preceitos católicos. Severino de fato conhecia a fundo as religiões, ou pelo menos o que Ihe foi transmitido pelos escritos populares tais como a Missão Abreviada, texto tradicional que circulou em Pau de Colher, publicado pelo padre Manoel José Gonçalves do Couto em 1867, uma espécie de bíblia resumida que teria sido disseminada na época das "Santas Missões", e popularizada pelas mãos dos beatos. ${ }^{48}$ Raimundo Estrela ${ }^{49}$ revela um Severino dado a intensas leituras religiosas, seus livros prediletos seriam a Bíblia, o livro de São Cipriano e a História de Carlos Magno. 50

É bem possível que esteja correta a afirmação de que ele "lia e relia a bíblia de cabeça para baixo". Peregrinos como Severino podiam perfeitamente ser analfabetos e declamar textos inteiros para a população apenas com o auxílio da memória e do que foi repassado por seus mestres. Sabemos que a tradição católica popular era produzida e reproduzida, sobretudo, pela fala, o que explica, em parte, 0 processo de re-significação dos ensinamentos religiosos não mais presos às escrituras. Além disso, o "falar enrolado", os "êxtases" e "visões", entre outros sintomas "sobrenaturais", eram prova cabal para seus seguidores de sua condição extraordinária, "santificada" que era posta à prova constantemente. Por isso os supostos dons sobre-humanos e milagrosos a todo o momento referendavam um ser que se dizia em contato com o plano sagrado.

\footnotetext{
48 DELLA CAVA, Ralph. Op. Cit., p. 38.

49 ESTRELA, Raimundo. Op. Cit., p. 32-34.

50 Impressiona na afirmação do autor a presença das histórias referentes à gesta carolíngia nos sertões nordestinos, visto que estas eram comumente encontradas mais ao sul, como no movimento do Contestado (1912-1916).
} 
O inabitual banho com as virgens não nos parece verossímil, pois encontramos em outros documentos relatos parecidos que tentam firmar a imagem de um Severino depravado, cafajeste e aproveitador de mulheres inocentes, que se vale de sua condição de líder e profeta para tirar proveito de pessoas que o veneram. Não podemos esquecer que a rigidez religiosa e moral do seu discurso condenavam justamente comportamentos libertinos como esses dos quais é acusado. Zé Lourenço também foi vitima de campanha caluniosa semelhante que afirmava existir em Caldeirão um harém de 16 mulheres que trabalhavam só para o beato. Além de libertino, também era chamado de glutão, pois diziam, com toda a fartura do Caldeirão, só comia do bom e do melhor.

Já os sacos cheios de sal permanecem um mistério para nós. Sabemos que o sal é considerado uma substancia valorizada por diversas religiões e crenças, utilizado tanto para sacrifícios humanos como para ritos de purificação. Hebreus e católicos tratam o composto, que é inclusive citado na Bíblia, como forma de conexão com o sagrado. Os habitantes de Pau de Colher, no momento do confronto com as tropas militares, se atiraram frente aos soldados tendo a certeza de que retornariam da pós-vida. Suspeitamos que o sal, que, aliás, era abundante em Casa Nova, esteja relacionado com esta atitude inesperada dos catingueiros, pois poderia - de acordo com a reportagem supracitada - os trazer de volta à vida.

Após a sua primeira experiência no cárcere em Remanso, na Bahia, Severino continuou com suas pregações que se voltaram então para o Ceará. Em 1936, foi ele novamente detido neste Estado, desta vez por agentes da Delegacia de Ordem Política e Social (DEOPS) ao pregar no lugar denominado Santa Quitéria e enviado para Fortaleza. Havia uma contundente suspeita de que Severino fosse remanescente da insurreição comunista de 1935, tendo em vista que era natural do Rio Grande do Norte, um dos focos da rebelião. Desta vez, permaneceu na mesma cela que famosos comunistas cearenses como Jader de Carvalho, entre outros. ${ }^{51}$ Nesse ínterim, Caldeirão foi destruído. Em 1937, com Severino já fora das grades, surgiu o boato de que ele estaria organizando os fanáticos do beato Lourenço, dispersados pela caatinga, para revidar um ataque à cidade do Crato.

De fato, um grupo remanescente do Caldeirão se instalou nos locais Mata dos Cavalos e Curral do Meio, na Serra do Araripe. Em pouco tempo, jornais de Fortaleza publicaram denuncias da presença de "fanáticos" perturbando a ordem pública nas fronteiras do Ceará com Pernambuco. Uma delas partiu de Norões Milfont, deputado da Junta Estadual da Liga Eleitoral Católica (LEC) ${ }^{52}$ e advogado dos

51 ALVES, Tarcísio Marcos. A Santa Cruz do Deserto. A Comunidade Igualitária do Caldeirão 1920/1937. Recife: Néctar, 2008, p. 182.

52 RAMOS, Francisco Régis Lopes. Op. Cit., p. 104. 
padres salesianos de Juazeiro. Milfont comunicou ao capitão Cordeiro Netto, chefe de polícia e secretário de segurança pública do estado do Ceará, por telegrama53: "O secretário do Beato José Lourenço, de nome Sebastião Marinho, ameaçava atacar a fazenda Conceição e a cidade do Crato". 54 Recebida a mensagem, esta foi transmitida pelo rádio ao capitão da Policia Militar, José Gonçalves Bezerra, que se encontrava em Juazeiro. Marinho era na verdade um morador de Caldeirão que supostamente fora enviado à cidade do Crato com o objetivo de adquirir alimentos para os que se escondiam na caatinga, mas acabou capturado. Bezerra logo formou uma diligência com 11 praças e no dia 10 de maio de 1937 partiu à procura dos "fanáticos", tendo como guia Marinho. ${ }^{55}$ Diz ele em telegrama ao chefe de polícia de Fortaleza antes de partir em viagem:

\begin{abstract}
"Juazeiro, 10 (7h $15 \mathrm{~min}$ ) - Chegou aqui o delegado de policia do Crato, pedindo socorro, pois aquela cidade esta sendo ameaçada de ataque por parte dos fanáticos, chefiados por Severino Tavares, êmulo do beato José Lourenço. Referido grupo de fanáticos estava localizado nos lugares Rasgão e Mata dos Cavalos, no sopé da Serra do Araripe, distante quatro léguas do Crato. Sigo nesta ocasião com a pequena força de que disponho, a fim de prender os mencionados fanáticos. Fica respondendo pelo comando desta companhia 0 tenente João Lima. Hoje ainda, direi o resultado da diligência - Cap. Bezerra, comandante da Cia". 56
\end{abstract}

Ao chegar à localidade denominada Cruzeiro, entre Crato e Conceição, a volante entrou em confronto com o grupo de Severino. Em entrevista, Netto diz que Marinho era pessoa de confiança de Zé Lourenço, seu agenciador e intermediário em transações comerciais. O capitão revela que investigações deram conta de que Marinho armou uma cilada para os policiais. ${ }^{57}$ Segundo o militar, a volante não teve chance de defesa:

Apenas o sargento Brasileiro apresenta um ferimento por arma de fogo. Os demais foram atacados a cacete e foice. $O$ ferimento mortal do capitão bezerra, que recebeu numerosas cacetadas, foi feito como já se noticiou, por uma foiçada, na nuca, que o prostou rebentando-

\footnotetext{
53 LUTA e morte na Serra do Araripe. O Povo, 11 de maio de 1937, p. 1 e 8.

54 Facó se refere a uma suposta cisão no Caldeirão, cuja responsabilidade seria de Severino, que liderava uma facção para resistir com armas às tropas militares em seu encalço. Zé Lourenço, ao contrário, manteria uma posição pacifista e de negociação. A versão é coerente com o depoimento de Manuel Ferraz que diz que nesse tempo a liderança de Severino Tavares ganhou força enquanto enfraquecia a do velho beato Lourenço. Mas não tomemo-la como verdadeira, pois como diz Facó: "pode também ter sido forjada com o objetivo de justificar uma ação "preventiva" das autoridades estaduais contra os "fanáticos". Ver: FACÓ, Rui. Op. Cit., p. 208; FERRAZ, Marilourdes. Op. Cit., p. 469.

55 SILVA, Judson Jorge da. e ALENCAR, Francisco Amaro Gomes de. Do sonho à devastação, onde tudo se (re) constrói: Experiências e Memórias nas Lutas por Terra da Região do Cariri-CE. Revista NERA, Presidente Prudente, n. 14, ano 12, p. 134, 2009.

56 LUTA e morte na Serra do Araripe. Op. Cit., p. 1 e 8.

57 IMPRESSIONANTES detalhes da chacina do Cariry. Diário da Noite, Recife, 18 de maio de 1937, p. 1.
} 
Ihe os miolos. 58

Existem versões conflitantes sobre o paradeiro de Severino após o episódio. Algumas reportagens dão conta de sua presença durante o ataque a Pau de Colher um ano depois, em 1938. Cordeiro Netto, que fez uma viagem a Pau de Colher após a sua destruição, ao retornar esclareceu alguns fatos para um grupo de jornalistas dos "Diários Associados". Na palestra, retratada no jornal Diário de Pernambuco, Netto afirma que uma reprodução dos fatos de Pau de Colher seria impossível, "dadas as medidas acauteladoras tomadas pelas policias da Bahia, Pernambuco e Ceará". 59 Mas os jornalistas insistem e perguntam se era verdade que Severino era o verdadeiro chefe do grupo, como faziam supor "telegrammas precedentes da Bahia e Recife". ${ }^{\circ 0}$ Ao que o secretário responde:

Asseguro, pelo menos, que o "beato" Lourenço não estava á frente da rebellião sertaneja, esta
vivendo no Crato e não penso siquer em mandar prende-lo pois leva uma vida pacifica. 0
"beato" Severino, pelo que sei, deve encontra-se muito longe do Cariry. ${ }^{61}$

Tal versão foi desmentida anos depois pelo filho de Severino, Eleutério, que afirmou ter enterrado o seu pai após os confrontos na serra do Araripe. Mas essa explicação não bate com as informações do Capitão Optato Gueiros, comandante das forças militares pernambucanas em Pau de Colher.

A repressão a Pau de Colher se dividiu em duas expedições ao reduto. Uma primeira em 10 de janeiro de 1938, formada por quatro praças da polícia militar baiana e 30 civis sob o comando do $3^{\circ}$ sargento Geraldo Bispo dos Santos, resultou na morte de dois soldados e quatro civis, pelo lado das forças militares e na perda de quatro "fanáticos", entre eles José Senhorinho, líder do grupo. Para a segunda expedição foi organizado o "Destacamento do Vale do São Francisco", congregando forças dos Estados da Bahia, Pernambuco e Piauí. Por motivos que não cabem citar aqui, a componente da Brigada Militar de Pernambuco, sob comando do Capitão Optato, atacou antecipadamente a comunidade em oito de fevereiro de 1938, promovendo um massacre que durou dois dias e duas noites e terminou com 400 vitimas fatais e muitos outros feridos e refugiados. Em relatório apresentado ao Secretário de Segurança Pública de Pernambuco, Etelvino Lins, o Capitão Optato diz que Severino

\footnotetext{
58 lbid. p. 8.

59 FOMENTADORES de perturbações sociaes provocaram a incursão dos bandoleiros no sertão. Diário de Pernambuco, Fortaleza, 30 de janeiro de 1938, p. 1.

60 lbid., p. 1.

61 lbid., p. 1.
} 
estava presente nos acontecimentos e fugiu logo no início da luta. Em seu livro de memórias, Optato fala ainda sobre o momento em que os moradores, ao serem atacados, davam vivas a Severino:

Os seus ataques, frontais, flanqueamentos e retaguarda, eram propostos, organizados e executados às nossas vistas, em alta voz e, aos brados de "viva meu Padrinho Conselheiro", avançavam desordenadamente como loucos. Daí o morticínio haver chegado a tais proporções. $[\ldots]^{62}$

E ao descrever o beato diz:

Entre esses crentes de José Lourenço, apareceu um individuo verdadeiramente imbuído da idéia de que era um enviado do céu. Chamava-se Severino Tavares [...] Tinha um timbre de voz atraente, aliado a um fraseado bem sedutor. Fascinou e dominou por completo toda aquela gente, até o próprio José Lourenço deixou-se levar pelas lábias do "colega". [...]

[...] fora empregado como caixeiro em uma mercearia na cidade de Santa Ana do cariri. Nas horas de lazer lia dois únicos livros: o livro de São Cipriano e a História de Carlos Magno. 63

A reportagem da Gazeta de Alagoas citada anteriormente diz que Quinzeiro, o suposto filho de Severino (ver nota 49), conseguiu convencer o pai a entregar o grupo de Pau de Colher à sua direção. Estava ele preocupado em preparar o povo para a luta contra as tropas pernambucanas que se aproximavam do reduto, informação que obteve de sentinelas perdidos na caatinga. Severino teria reunido todos os moradores de Pau de Colher e convencido-os de que Quinzeiro era um "enviado de Deus" e fazia baixar o "Divino Espírito Santo" sempre que quisesse. Logo, estariam todos protegidos sob seu comando.

No dia do ataque, Quinzeiro teria se escondido nas redondezas com outros 100 homens de onde assistiu ao embate dos moradores com as tropas do governo. "Nessa luta os fanáticos se batiam com verdadeiro denodo e avançavam contra os soldados do governo, armados de paus, foices, facões, fuzis, rifles, e etc..", diz o texto.64 Investigações posteriores, que incluíam depoimentos de sobreviventes, confirmaram que Severino Tavares não se encontrava em Pau de Colher nos dias do combate, tornando seu paradeiro final, um fato desconhecido.

\section{SEVERINO E A ESPERANÇA MESSIÂNICA}

Se Severino nos permitiu estabelecer o vínculo entre os três movimentos já citados, nos intrigou o fato de Pau de Colher ter seus condicionantes remotos no movimento de Juazeiro, uma vez que este

62 GUEIROS, Optato. Lampeão: Memória de um oficial ex-comandante de forças volantes. Recife: 1952, p. 18.

63 GUEIROS, Optato. Op. Cit., p. 66 e 253.

64 AS INCURSÔES do beato José Lourenço através dos sertões nordestinos. Op. Cit., p. 8. 
não demonstrou, ao longo de sua história e das análises já disponíveis sobre o caso, sinais contundentes de manifestação messiânica. Eles, entretanto, existiram e foram deliberadamente cerceados por Padre Cícero. Acreditamos que Severino Tavares e Zé Lourenço foram os responsáveis por resgatá-los e reinventá-los, influenciando a formação do messianismo em Pau de Colher anos mais tarde.

O sociólogo Duglas Monteiro, em texto clássico, já apontava para a existência de "crenças de tipo milenarista e messiânico" na atuação de Cícero em Juazeiro, mas por ele restringidas. Exemplo inequívoco para o autor é o que se pode chamar de uma "teofania inaugural" - o sonho-visão de Cícero - como componente escatológico da mitologia de Juazeiro. Se não ocorreu a elaboração de um consistente corpo ideológico de natureza messiânica e milenarista, os elementos para isso existiram "acentuando-se em certos momentos, para voltar à latência durante longos períodos". 65

Se a "quimera" de Cícero foi elemento principiador para elaboração da referida teofania, as novas proposições teológicas advindas do "Milagre do Sangue" teriam um papel fundamental no desenvolvimento dos movimentos posteriores de Caldeirão e, sobretudo, em Pau de Colher. Tais propostas foram exploradas com mais detalhe por Ralph Della Cava a partir de documentos até então inéditos - como um panfleto de 1891 intitulado: "Os milagres de Joaseiro ou Nosso Senhor Jesus Christo Manifestando sua Presença Real no Divino e Adorável Sacramento da Eucharistia"66 explicitando o que seria a formulação da idéia de uma segunda redenção - confirmada caso fosse de fato o sangue de Jesus a verter da boca da beata Maria do Araújo - algo que contrariava frontalmente 0 escarmento católico de uma redenção única. ${ }^{67}$ Outrossim, a manifestação de Cristo em Juazeiro, para Cícero e sua beata, sugeriria a aproximação do fim dos tempos, do dia do Juízo Final, da chegada do tempo do "acerto de contas". De acordo com Della Cava:

A pedra de toque da fé popular propagada pelas beatas era uma visão apocalíptica da iminente destruição do mundo. Da mesma forma que os padres dissidentes do Cariri, as beatas chamavam atenção para a recente derrubada da monarquia brasileira e para a recémdecretada autoridade da República sobre o matrimônio, o que era, até então, domínio exclusivo

\footnotetext{
65 MONTEIRO, Douglas Teixeira de. Um confronto entre Canudos, Juazeiro e Contestado. In: FAUSTO, B. (org.) História Geral da Civilização Brasileira, Tomo III - O Brasil Republicano, II Vol.: Sociedades e Instituições (1889-1930). São Paulo/ Rio de Janeiro: Difel, 1978, p. 55.

${ }_{66}^{6}$ DELLA CAVA, Ralph. Op. Cit., p. 39 e 40.

${ }^{67}$ Em portaria de 5 de agosto de 1892, Dom Joaquim suspendeu Padre Cícero, proibindo-o de confessar, pregar e orientar os fiéis. Podia apenas celebrar missas. Entre as sete justificativas alencadas para tais medidas, pode-se ler: [...] 3) Por sustentar e inculcar doutrinas audaciosas, supostamente a da segunda Redenção; [...]. Ver: DELLA CAVA, Ralph. Op. Cit., p. 83.
} 
da Igreja. Consideravam-se essas duas mudanças como sinais do juízo final. ${ }^{68}$

Se esses novos desígnios religiosos eram a matéria-prima para a exacerbação dos sentimentos de devoção ao redor de Padre Cícero, este tratou de limitá-los intencionalmente. É o que indica, por exemplo, um trecho do discurso de Floro Bartholomeu, médico e político, amigo de Padre Cícero, feito na Câmara Federal em 1923. ${ }^{69}$ Refutando acusações infundadas contra o sacerdote, ele cita a tentativa de Padre Cícero para limitar a circulação de medalhas com seus retratos (encontradas anos depois em Pau de Colher), que segundo seus opositores eram produzidas com o intento de vangloriar a sua própria figura:

\begin{abstract}
Não podendo evitar a circulação por todos os sertões do Nordeste, por serem espalhadas pelas grandes praças commerciais, que vendiam em grozas aos negociantes do interior, e já estando por demais acabrunhado com as accusações que lhe eram feitas pelos padres e pelos bispos em continuados sermões, como autor e responsável pela circulação das referidas medalhas, dirigiu uma carta, que foi entregue por mim, ao illustre padre lazarista Jeronymo Castro, então professor do Seminário de Fortaleza, de toda confiança do arcebispo D. Manoel Gomes.

Nessa missiva, cuja cópia possuo, o padre Cícero pedia-lhe que se entendesse com aquelle diocezano, no sentido de prohibir a venda das medalhas nas casas commerciais de Fortaleza e obter que seu collega de Recife fizesse o mesmo. ${ }^{70}$
\end{abstract}

A atitude de Cícero de interpelar um de seus pares no sentido de lhe ajudar na interrupção do trânsito das medalhas é um forte elemento que indica sua predisposição em diminuir as ações populares que visavam a santificação de sua imagem. Mais do que isso, ele tentava, continuamente, manter-se próximo à Igreja, ao jurar lealdade a Roma e recorrer aos potentados do interior para desviar de si a hostilidade da instituição eclesiástica. ${ }^{71}$ Essa aproximação também o forçava a manter sob rédea curta os beatos e as beatas mais exaltados que atuavam a seu lado, como Zé Lourenço, citado em outra parte do discurso de Bartholomeu:

\footnotetext{
Esse preto, quando ali chegou, já era "penitente" em sua terra, isto é, fazia parte de uma associação officiosa, fundada pelos antigos missionários e ainda hoje tolerada por um ou outro padre

O intuito desses "penitentes" era, sem prejuízo dos seus trabalhos, uma ou outra noite da semana, á hora alta, reunidos em grupo avultado, e em trajes amortalhados, rezarem officios
}

\footnotetext{
68 DELLA CAVA, Ralph. Op. Cit., p. 68.

69 Seu pronunciamento foi uma resposta à conferência "Impressões sobre o Nordeste" que o Dr. Paulo Moraes e Barros realizou na Associação dos Empregados do Comércio do Rio de Janeiro, em que relatava observações de uma viagem que fez a Juazeiro e, segundo o próprio Bartholomeu "vomitou cobras e lagartos" sobre a cidade e seu patriarca.

70 COSTA, Floro Bartholomeu da. Joazeiro e o Padre Cícero. Rio de Janeiro: Imprensa Nacional, 1923, p. 76.

71 DELLA CAVA, Ralph. Op. Cit., p. 96.
} 
pelas almas nos cemitérios e junto a cruzes das sepulturas nas estradas do sertão. Essa pratica era intercalada das "disciplinas", isto é, elles com uns aparelhos especiaes, que os antigos padres inventaram, se feriam superficialmente nas costas. E os missionários davam 0 exemplo.

No Crato e em todo o Cariry, até certo tempo, padres como Felix de Moura, monsenhor Monteiro, Felix Arnaud e outros assim faziam.

0 padre Cícero foi quem acabou, no Joazeiro, com o uso ostensivo. ${ }^{72}$

Padre Cícero, portanto, não estimulava práticas de natureza messiânica ou de idolatria, mas independentemente de sua vontade, elas proliferaram. Em Caldeirão, as citações ao sacerdote eram constantes nas prédicas de Zé Lourenço que sempre lembrava seus conselhos e narrava importantes episódios de sua trajetória. Lopes ressalta um detalhe importante: o beato não era apenas um transmissor das determinações de Cícero. "Não se tratava propriamente de uma transmissão de ordens, mas de uma espécie de legitimação simbólica que José Lourenço encontrava na figura de 'Padim Circo'" ${ }^{73}$ Em outras palavras, Zé Lourenço acreditava nas palavras e utilizava o prestigio de seu mestre para conquistar mais fiéis e para fundamentar as práticas religiosas que implementou na comunidade.

Outra questão que nos parece oportuna citar é a que está relacionada diretamente ao testamento de Padre Cícero, datado de $1923^{74}$, no qual doara suas terras à ordem dos padres salesianos, incluindo o sitio do Caldeirão. ${ }^{75} \mathrm{~A}$ situação gerou um sério conflito entre Zé Lourenço e os padres, que decidiram fazer valer de seus direitos, sem pagar nenhuma indenização ao beato, que havia promovido extensas melhorias no terreno. Norões Milfont, deputado da Junta Estadual da Liga Eleitoral Católica (LEC), já citado anteriormente, foi então contratado para defender a causa dos salesianos e não tardou a divulgar que o beato escondia armas em Caldeirão e a comunidade era um

72 COSTA, Floro Bartholomeu da. Op. Cit., p. 97.

${ }^{73}$ RAMOS, Francisco Régis Lopes. Op. Cit., p. 92.

74 Padre Cícero fez dois testamentos, o primeiro em 1922 foi substituído por um segundo de 1923 no qual fundamenta as razões para a doação de suas propriedades para uma instituição pia e de caridade, como a ordem dos padres salesianos, que dariam continuidade à sua obra religiosa. Os salesianos, assim como os capuchinhos, contribuíram para a consolidação do mito em torno de Cícero no Cariri. Fundaram e dirigiram uma capela sob a invocação do Sagrado Coração de Jesus, na Serra do Catolé ou Serra do Hôrto, como era conhecida pela população, onde Padre Cícero mandou construir um templo, obra que não chegou a ser concluída por ordem do bispo $D$. Joaquim. Sua estrutura inacabada que chegou a atingir $20 \mathrm{~m}$ de altura também foi doada aos salesianos. Ver: ANSELMO, Otacílio. Padre Cícero: mito e realidade. Rio de Janeiro: Civilização Brasileira, 1968, p. 106.

75 "Em nome de Deus Amém. Eu, padre Cícero Romão Batista, achando-me adoentado, mas sem gravidade, e em meu perfeito juízo, e na incerteza do dia de minha morte, tornei a resolução de fazer o meu testamento e as minhas ultimas disposições, para o fim de dispor de meus bens, segundo me permitem as leis do meu país. [...] Deixo para a Ordem dos Salesianos [...] os terrenos que possuo na Serra do Araripe [...]; as fazendas Letras, Caldeirão e Monte Alto [...]." Ver: LOURENÇO FILHO, Manoel Bergstrom. Juazeiro de Padre Cícero. Brasilia: INEP/MEC, 2002, p. 157. 
mal semelhante a Canudos. ${ }^{76}$ Os próprios salesianos falavam em suas missas do perigo que representava o ajuntamento dos fanáticos, infiltrado por "agentes vermelhos a serviço do totalitarismo ateu", uma séria ameaça ao Estado e à Igreja. ${ }^{77}$

0 posicionamento de Padre Cícero em relação à propriedade do Caldeirão é revelador. Apesar de o testamento ter sido elaborado três anos antes da instalação de Zé Lourenço no sítio, nada impediria Cícero de modificá-lo posteriormente e doá-lo definitivamente ao seu fiel seguidor. Preferiu mantê-lo nas mãos dos salesianos que, após a sua morte em 1934, reivindicaram seu bem. Nossa hipótese é de que ele condenava as práticas promovidas ali por Zé Lourenço, mas não queria se comprometer em retirá-lo de lá, trabalho que ficou a cargo dos salesianos, os quais poderiam controlar 0 ímpeto do beato, sem grandes embaraços. ${ }^{78}$

Pereira de Queiroz insere a comunidade do Caldeirão no grupo dos movimentos messiânicos rústicos, mas Régis Lopes discorda dessa posição. Segundo ele, nas conversas que manteve com sobreviventes, a idéia fundamental do messianismo, isto é, a "esperança da chegada de um redentor", não teve lugar em Caldeirão. Motivações religiosas existiram, mas não de caráter messiânico. Segundo o autor "o que atraía gente para a comunidade e motivava a construção de uma sociedade cooperativista estava profundamente ligado com a mentalidade do Catolicismo Popular", e nisso apenas. $^{79}$

Mas o fato é que Zé Lourenço reformulou os ensinamentos transmitidos por Padre Cícero, estruturou uma liderança carismática que por sua vez, moldou a forma de atuação de seus seguidores, entre eles Severino Tavares. Mesmo Lopes admite que "alguns elementos do messianismo estavam presentes, de uma forma tímida e com raridade, nas prédicas de Severino Tavares acerca do Caldeirão" ${ }^{80}$ Como sabemos, Severino se dizia representante de Zé Lourenço e enviado de Padre Cícero, estratégia que Ihe serviu para aliciar muitos fiéis pelos sertões. Seu proselitismo, entretanto, desagradava não apenas as autoridades, mas ao próprio Padre Cícero, como podemos observar numa carta na qual o sacerdote responde a um pequeno proprietário de terras que lhe indagava sobre os conselhos de Severino:

\footnotetext{
${ }^{76}$ ALVES, Tarcísio Marcos. Op. Cit., p. 179.

77 CARIRY, Rosemberg. O beato José Lourenço e o Caldeirão de Santa Cruz. Revista Itaytera, Crato, n.26, 1982, p. 195.

78 Discordamos, portanto, da afirmação de Régis Lopes que entende que Cícero não alterou seu testamento porque achava que os salesianos não iriam se posicionar contra o trabalho comunitário dos sertanejos. Pensamos que ele não alterou 0 texto testamentário justamente pelo motivo inverso: os padres dariam conta de sumir com a já perigosa comunidade do Caldeirão. Ver: RAMOS, Francisco Régis Lopes. Op. Cit., p. 103.

79 RAMOS, Francisco Régis Lopes. Op. Cit., p. 187.

80 RAMOS, Francisco Régis Lopes. Op. Cit., p. 183.
} 
Joaseiro, 5 de setembro de 1932
Amigo Sr. Félix Virgulino de Sena
Recebi sua carta de 23 de agosto e passo a responde-la

Esse Severino Tavares que andou ahi inquietando a sua família, é um pobre maluco, a quem ninguém deve ligar importância sobretudo para dar crédito às asneiras que anda pregando no meio do povo ignorante.

Nunca the dei e nem podia dar autorização para andar se prevalecendo de meu nome para coisa alguma

Peço-lhe, portanto, como especial obséquio que, não só aos membros da sua família que se deixaram influenciar por esse pobre homem, como a todos os que com ele convierem ahi, diga, em meu nome, que elle é simplesmente um maluco, em quem ninguém deve acreditar.

Quanto ao senhor, aconselho-o a não vender absolutamente as suas propriedades, nas quais deve continuar a trabalhar, com os seus filhos e netos.

Se algum destes se obstinar em continuar a dar crédito às asneiras de Severino Tavares, mande este até aqui para eu, de viva voz, Ihe reproduzir o que digo nesta carta e convencê-lo de que deve, em obediência aos seus desejos, permanecer ahi, trabalhando como o sr. na terra onde nasceram e se criaram.

\title{
Pe. Cícero Romão Batista 81
}

Nota-se que o Sr. Félix pretendia vender suas propriedades, um indício de que possivelmente ele e sua família acompanhariam Severino em suas andanças. Era prática costumeira das populações sertanejas venderem suas terras, ou simplesmente abandoná-las, pagar suas dívidas e unir-se aos beatos e conselheiros que combatiam a acumulação de bens materiais. Cid Carvalho, em artigo de 1938, já mencionado, confirma esse hábito:

\begin{abstract}
Além desses factos, contam-se as centenas de explorações de caráter pecuniário, pelas quaes innumeros sertanejos proprietários e criadores de desfizeram dos seus haveres, adquiridos á custa de tantos sacrifícios, para entregarem ao beato o produto dos mesmos, visando a compra de "uma posse de terra no céo", afim de para lá se transportarem quando chegassem a hora da "salvação"82
\end{abstract}

Mas voltemos à carta de Padre Cícero. O mais significativo para os objetivos deste trabalho é que ela traduz uma veemente condenação das pregações do beato por parte do sacerdote, o que corrobora a hipótese de que ele temia e tentava, na medida do possível, restringir manifestações messiânicas que mantinham algum diálogo com Juazeiro, o que não impediu seus seguidores e

81 SILVA, Antenor de Andrade. Cartas do Padre Cícero (1877-1934). Salvador: Ed. E. P. Salesianas, 1982, p. 180-181.

82 FANATISMO dissolvente e destruidor. Op. Cit. 
admiradores de as retomarem (e as reinventarem), além de utilizar seu nome e sua autoridade como forma de valorização de um sectarismo próprio.

Suspeitamos que o papel de Severino causasse mais preocupação às autoridades constituídas do que imaginávamos no início desta pesquisa, alcançando, inclusive, as praças das principais capitais do país. Em edição de 1938, O Jornal, do Rio de Janeiro, reproduziu matéria do repórter Azevedo Marques que relata o seguinte caso sobre Severino:

No trem encontro 0 antigo diretor da viação bahiana o qual me relata o seguinte:

"Há cerca de dois annos, encontrei numa praça da cidade de capella um grande ajuntamento popular. Procurando investigar do que se tratava, vi ali falando ao povo, o mulato Severino, o qual se dizia "enviado do beato Lourenço", substituto do Padre Cícero."

Achava-se elle hospedado na fazenda "Caldeiras", cercado das homenagens e das reverências de centenas de pessoas, muitas delas de condição social superior. 0 "beato" Severino revelava aos circumstantes a missão que o levava àquella cidade: a de salvar todos os quantos o quizessem acompanhar.

Prophetizava uma chuva de sangue, que inundaria tudo. Falava com um certo desembaraço, se bem que usasse uma linguagem pobre e mal arranjada, revelando a sua quase completa ignorância. Tive a impressão de que 0 orador mal saberia, talvez, ler e escrever.

Dizia o "beato" Severino que os ricos deveriam dar as suas riquezas aos pobres para encontrar a salvação. Os pobres deveriam todos reunir-se e, em romaria, seguir para junto do "beato" Lourenço afim de perseguir o anti-christo.

0 meu interlocutor adiantou que mandou chamar Severino, reprehendendo-o duramente pela sua exploração da crendice popular e ameaçando-o de mandar prendêl-o, caso não abandonasse immediatamente a cidade. De facto, o "beato Severino desappareceu logo após, dirigindo-se a Casa Nova.

Acredita o meu informante que esse mesmo embusteiro tenha organizado o grupo de fanáticos de Colher de Pau. ${ }^{83}$

Vale notar que o discurso de Severino referido na reportagem comprova, mais uma vez, a forte apologia que o beato fazia de Caldeirão e Zé Lourenço, o que iremos encontrar também em Pau de Colher. A forte pregação apocalíptica que profetizava uma "chuva de sangue" que inundaria o sertão e a obrigação dos ricos remediarem os pobres condiz com o mito milenarista difundido nos sertões nordestinos de que apenas os bem-aventurados desfrutariam da paz e felicidade do Reino dos Mil Anos a ser inaugurado após a batalha final entre Cristo e o "Anti-christo". A guerra entre o bem e o mal só poderia ser vencida na arena do Caldeirão, onde se encontrava Zé Lourenço, que antecedendo a segunda vinda de Cristo, podia ser considerado, entre essas pessoas, o Salvador Terreno dos Últimos Dias, como fora antes identificado também Padre Cícero.

Podemos ainda indicar que o mito acerca do Caldeirão foi levado por Severino a Pau de Colher

${ }^{83}$ POSSIVEL infiltração do communismo nas hostes fanáticas do nordeste. O jornal, Rio de Janeiro, 1 de fevereiro de 1938. 
e serviu como substrato para crenças milenaristas. Não menos importante foi a estrutura hierárquica que encontramos em Pau de Colher, com a divisão por cargos entre as lideranças, com funções específicas para o bom funcionamento da irmandade, claramente influenciada pelos ensinamentos levados pelo beato. Da mesma forma que algumas pistas nos indicam que Severino reelaborou princípios gestados em Juazeiro e Caldeirão, uma nova liderança, Senhorinho, formado sob sua orientação, terá comportamento semelhante em Pau de Colher.

Severino, portanto, deve ser entendido como um agente que propiciou a circulação de idéias e crenças que sentam raízes em Juazeiro do Norte e na atuação, consciente ou não, de Padre Cícero na formação de beatos e beatas, que alimentavam sua fé a partir das novas proposições teológicas do "Milagre da Hóstia". O segundo advento de Cristo seria seguido por um tempo de mil anos marcado pelo sentimento de esperança e a renovação das almas pecadoras teria início em Juazeiro do Norte, uma terra santificada. Com a morte de Cícero, o espaço sagrado apenas mudou de lugar. Em Caldeirão, comunidade que propiciou a Severino seu primeiro contato com a próspera religiosidade popular e onde concluiu sua formação religiosa, desenvolveu-se intensamente, um claro sinal para seus habitantes de que Zé Lourenço era um homem de poderes especiais e, de acordo com vários relatos, era considerado muitas vezes a própria encarnação de Padre Cícero.

Caldeirão não resistiu à investida das forças do Estado, mas a semente do messianismo já estava plantada em outro lugar, Pau de Colher, levada pelas palavras de Severino que por onde passou arregimentou asseclas e tentou convencê-los da aproximação do Apocalipse. Severino, segundo averiguamos, corporificava como verdadeiro cristão o próprio Espírito Santo ao lado de Padre Cícero (Deus Pai) e Zé Lourenço (Deus Filho), completando assim, a Santíssima Trindade, manifestada em todas as ações milagrosas que esses personagens revelaram ao longo dos anos. A mensagem que 0 beato tentava transmitir era, portanto, clara: três pessoas tocadas pela graça divina, três santos em perfeita comunhão.

\section{BIBLIOGRAFIA}

1. ALVES, Tarcísio Marcos. A tragédia da comunidade camponesa igualitária do sítio Caldeirão. Clio. Revista de Pesquisa Histórica. Recife: Ed. Universitária, n. 19, p. 55-64, 2001.

2. ANSELMO E SILVA, Otacílio. Padre Cícero: Mito e realidade. Rio de Janeiro: Ed. Civilização Brasileira, 1968.

3. AZEVEDO, Thales de. 0 catolicismo no Brasil: um campo para a pesquisa social. Rio de Janeiro: Ministério da Educação e Cultura, 1955. 
4. AZZI, Riolando. O movimento de reforma católica durante o século XIX. Revista Eclesiástica Brasileira, Petrópolis, n.34, p. 656-662, 1974.

5. $\quad$. 0 catolicismo popular no Brasil: aspectos históricos. Petrópolis: Vozes, 1978. (Cadernos de Teologia e Pastoral; 11).

6. BASTIDE, Roger. Brasil: terra de contrastes. São Paulo - Rio de Janeiro: Difel, 1973.

7. BOAVENTURA, Edivaldo M. O centenário de Luiz Viana Filho 1908-2008. Revista do IHGB, Rio de Janeiro, a. 169 , n. 439, p. 225-232, 2008.

8. BRITO, Gilmário Moreira. Pau de Colher: Na letra e na Voz. São Paulo: EDUC/FAPESP, 1999.

9. BULHÕES, Antonio Maria de Oliveira. Estudos definitivos de Alagoinhas ao Joazeiro e Casa Nova. Rio de Janeiro: G. Leuzinger, 1874.

10. CARONE, Edgar. A República Velha (evolução política). São Paulo: Difel Editora,

11. 1971.

12. CARIRY, Rosemberg. O beato José Lourenço e o Caldeirão de Santa Cruz. In: Revista Itaytera, Crato, n.26, p.189-199, 1982.

13. CASTALDI, Carlo. A aparição de demônio em Catulé. In: QUEIROZ, Maria Isaura Pereira de et al. Estudos de sociologia e história. São Paulo, Inep - Anhembi, p. 17-130, 1957.

14. CASTRO, Chico. A coluna prestes no Piauí. Brasília: Edições do Senado federal, 2007.

15. COHN, Norman. Na Senda do Milênio. Editorial Presença: Lisboa, 1981.

16. CORDEIRO, Domingos Sávio de Almeida. Caldeirão de Santa Cruz: memórias de uma utopia comunista no nordeste Brasileiro. In: VI Congresso Português de Sociologia. Mundos Sociais: Saberes e Praticas. Portugal: Universidade Nova de Lisboa, 2008.

17. COSTA, Emília Viotti da. Da Monarquia à República - momentos decisivos. São Paulo: Grijalbo, 1977.

18. COSTA, Floro Bartholomeu da. Joazeiro e o Padre Cícero. Rio de Janeiro: Imprensa Nacional, 1923.

19. CUNHA, Euclides. Os Sertões. Rio de Janeiro: Liv. Francisco Alves, 13 ed., 1936.

20. DELLA CAVA, Ralph. Milagre em Joazeiro. Rio de Janeiro: Paz e Terra, 1976.

21. DUARTE, Raymundo. Notas preliminares de estudo do movimento messiânico de Pau de Colher. In: IV Colóquio Internacional de Estudos Luso-Brasileiros. Salvador, 1969.

22. Uـ Um movimento messiânico no interior da Bahia. In: SCHADEN, Egon (org.). Homem, Cultura e Sociedade no Brasil, Petrópolis: Vozes, p. 326-250, 1972. (Seleções da Revista de Antropologia).

23. O O movimento messiânico de Pau de Colher. In: Cadernos do CEAS, Salvador, Centro de estudos e ação Social, 1997.

24. DUQUÉ, Ghislaine. Casa Nova: interventions du pouvoir et strategies paysannes. Un "municipe" du "sertão bahiano" à l'heure de La modernisation. 1980, 405 f. Thèse (Doctorat) - $3^{\circ}$ Cycle en Sociologie, Ecole Des Hautes Etudes en Sciences Sociales, Paris.

25. ESTRELA, Raimundo. Pau-de-colher: um pequeno Canudos. Salvador: Assembléia Legislativa do Estado da Bahia, 1998. 
26. FACÓ, Rui. Cangaceiros e fanáticos. Gênese e lutas. Rio de Janeiro: Civilização Brasileira, 1963.

27. FAUSTO, Boris. A revolução de 30. História e historiografia. São Paulo: Brasiliense, 1970.

28. FREYRE, Gilberto. Casa-grande e Senzala: formação da família brasileira sob o regime da economia patriarcal. Rio de Janeiro: José Olympio, 1980.

29. GUIMARÃES, Alba Zaluar. Os movimentos messiânicos brasileiros: uma leitura. BIB, Rio de Janeiro, Nº 6, p.9-21, 1979.

30. HERMANN, Jacqueline. História das Religiões e das Religiosidades. In: Ronaldo Vainfas e Ciro Cardoso. (Org.). Domínios da História. Ensaios de Teoria e Metodologia. Rio de Janeiro: Campus, vol. 1, p. 329-354, 1997.

31. No reino do desejado. A construção do sebastianismo em Portugal. Séculos XVI e XVII. São Paulo: Companhia das Letras, 1998.

32. HOORNAERT, Eduardo (coord.). História da Igreja no Brasil: ensaio de interpretação a partir do povo. Petrópolis: Vozes, 1983, Tomo II/Vol. I (História Geral da Igreja na América Latina).

33. LANTERNARI, Vittorio. As religiões dos oprimidos: um estudo dos modernos cultos messiânicos. São Paulo: Perspectiva, 1970.

34. LEANDRO, Ana Lúcia Aguiar Lopes. Movimento de Pau de Colher na perspectiva dos atores sociais: relações entre significações da religião e da miséria. 2003, 160 f. Dissertação (Mestrado em Sociologia) - Centro de Filosofia e Ciências Humanas, Universidade Federal de Pernambuco, Pernambuco, 2003.

35. MALVEZZI, Roberto. A história de Pau de Colher - o último grande movimento

36. messiânico do Brasil. s.d. (mimeo).

37. MARTINS-COSTA, Ana Luiza Borralho. Uma retirada insólita: a representação camponesa sobre a formação do Lago de Sobradinho. 1989, 322 f. Dissertação (Mestrado) - Programa de Pós-Graduação em Antropologia Social, Universidade Federal do rio de Janeiro, Rio de Janeiro.

38. MARTINS, Paulo Henrique de Souza e VASCONCELOS, Gabriel Assis Araújo. O Caldeirão do beato José Lourenço: fé, trabalho e luta social. I colóquio de história da UFRPE: Brasil e Portugal: nossa história ontem e hoje, Recife, 2007.

39. MELLO, Maria Alba Guedes Machado. História política do Baixo Médio São Francisco. Dissertação de mestrado em Ciências sociais na UFBA, 1989.

40. O movimento messiânico de Pau de Colher (uma reconstituição histórica). Revista da Bahia. Salvador: v.33, n.19, 1991.

41. MONTEIRO, Duglas Teixeira de. Os errantes do novo século - um estudo sobre o surto milenarista do Contestado. São Paulo: Duas Cidades, 1974.

42. __. Um confronto entre Canudos, Juazeiro e Contestado. In: FAUSTO, B. (org.) História Geral da Civilização Brasileira, Tomo III - O Brasil Republicano, II Vol.: Sociedades e Instituições (1889-1930). São Paulo/ Rio de Janeiro: Difel, p. 41-92, 1978.

43. Moura, Luiz Gomes de. CALDEIRÃO: o mundo futuro já presente aqui. Cadernos CTCH, UNICAP, nº 06, p. 37-45, 1998. 
44. NEGRÃO, Lisías N. e CONSORTE, J. G. 0 messianismo no Brasil contemporâneo. São Paulo: FFLCH-USPCER, 1984.

45. NEGRÃO, L. N. Revisitando o messianismo no Brasil e profetizando seu futuro. Revista Brasileira de Ciências Sociais, vol. 16, n. 46, 2001, p. 119-129.

46. PEREIRA DE QUEIROZ, Maria Isaura. 0 messianismo no Brasil e no mundo. São Paulo: Dominus/Edusp, 1965.

47. 0 campesinato Brasileiro. Ensaios sobre civilização e grupos rústicos no Brasil. Petrópolis: Editora Vozes, 1976. (Estudos brasileiros/3).

48. PIERSON, Donald. O homem no Vale do São Francisco. Rio de janeiro: Ministério do Interior, 1972.

49. POMPA, Maria Cristina. Memória do fim do mundo: para uma leitura do movimento Sócio-religioso de Pau de Colher. 1995, 160 f. Dissertação (Mestrado em Antropologia) - Instituto de Filosofia e Ciências Humanas, Universidade Estadual de Campinas, Campinas.

50. _. A construção do fim do mundo. Para uma releitura dos movimentos sócio-religiosos do Brasil rústico. Revista de Antropologia, São Paulo, vol. 41, n. 1, São Paulo, 1998.

51. QUEIROZ, Mauricio Vinhaz de. Messianismo e conflito social. A guerra sertaneja do Contestado: 1912-1916. Rio de Janeiro: Civilização Brasileira, 1966.

52. QUEIROZ, Renato da Silva. A caminho do paraíso - o surto messiânico-milenarista do Catulé. São Paulo: Centro de Estudos da Religião, 1995.

53. __ Mobilizações sócio-religiosas no Brasil: os surtos messiânico-milenaristas. Revista USP, São Paulo, n.67, p.132-149, setembro/novembro de 2005.

54. RAMOS, Francisco Régis Lopes. Caldeirão. Fortaleza: EDUECE, 1991.

55. SAMPAIO, Theodoro. 0 Rio São Francisco e a Chapada Diamantina. São Paulo: Companhia das Letras, 2002.

56. SANTOS, Israel Silva dos. Igreja Católica na Bahia. A Reestruturação do Arcebispado Primaz (1890-1930). 2006, 158 f. Dissertação (Mestrado em História) - Faculdade de Filosofia e Ciências Humanas, Universidade Federal da Bahia, Salvador.

57. SILVA, Antenor de Andrade. Cartas do Padre Cícero (1877-1934). Salvador: Ed. E. P. Salesianas, p. 180-181, 1982.

58. SILVA, Francivaldo Mendes da. Pau de Colher: narrativas de luta e fé no sertão da Bahia. 2008, $155 f$. Dissertação (Mestrado) - Centro de Filosofia e Ciências Humanas, Univercidade federal de Pernambuco, Recife.

59. SILVA, Judson Jorge da. e ALENCAR, Francisco Amaro Gomes de. Do sonho à devastação, onde tudo se (re) constrói: Experiências e Memórias nas Lutas por Terra da Região do Cariri-CE. Revista NERA. Presidente Prudente: ano 12, n. 14, p. 134, 2009.

60. SILVA, Lemuel Rodrigues da. e JUNIOR, Orivaldo Lopes. Catolicismo popular e migração no nordeste: os sertanejos do rio grande do norte em busca do "Paraíso Cristão". In: BINGEMER, Maria Clara Luchetti; NEUTZLING, Inácio e MAC DOWELL, João A. (orgs). A Globalização e os Jesuítas. Origens, História e impactos. Belo Horizonte: Faculdade Jesuíta de Filosofia e Teologia, 2006.

61. SODRÉ, Nelson Werneck. História militar do Brasil. Rio de Janeiro: Civilização brasileira, 1965. 
62. SOUZA, Laura de Mello e. 0 diabo e a Terra de Santa Cruz: feitiçaria e religiosidade popular no Brasil colonial. São Paulo: Companhia das Letras, 1986.

63. TAVARES, Luis Henrique Dias. História da Bahia. São Paulo/Salvador: EDUNESP/ EDUFBA, 2001.

64. VILAÇA, Marcos Vinicius e ALBUQUERQUE, Roberto C. Coronel e coronéis. Rio de Janeiro: Tempo Brasileiro 1965.

Artigo recebido em: 22/04/2010

Aceito para publicação em: 23/05/2010 